\title{
SENTENCE FRAGMENTS IN SEA TEACHER BLOG WRITING IN ST.PAUL UNIVERSITY SURIGAO, PHILIPPINES
}

\author{
Beny Arum Setianingsih ${ }^{* 1}$, Entika Fani Prastikawati*2 ${ }^{*}$ Wiyaka ${ }^{* 3}$ \\ benyyworks@gmail.com*1 $^{*}$, entikafani@upgris.ac.id ${ }^{* 2}$, alwi28birin@gmail.com*3 \\ Language and Arts Faculty ${ }^{* 123}$ \\ Universitas PGRI Semarang*123
}

\begin{abstract}
This study aimed at identifying fragments found on online diaries of 6th batch SEA Teacher blog writing in St. Paul University Surigao, Philippine, and to describe the problems faced by 6th batch SEA Teacher participants in writing online diaries. A quantitative method was carried out in this study. The instrument used for this study was ten formal online diaries of SEA teacher students which were downloaded from the website of SEA Teacher blog. When analyzing ten formal online diaries, the researchers found some kinds of fragments on seven formal online diaries. The most significant fragment realized was missing verbs $(56.52 \%)$. It was then followed by missing subject $(30.43 \%)$, added detail fragment $(8.70 \%)$, and -ing fragment $(4.34 \%)$. Whereas, the problems faced by 6th batch SEA Teacher participants in writing online diaries were lack of grammar knowledge, time limitation, limited reference, and the different language used. Further research is needed by involving more data of online writing to reveal the other sentences' mistakes.
\end{abstract}

Keywords: sentence fragment, blog, writing

DOI: https://doi.org/10.31943/wej.v4i2.94

\section{INTRODUCTION}

In this modern world, English is becoming a global language that should be mastered to communicate with people among nations (Hingne, 2013). As the most popular language, English is adapting to the fast-changing world. The vast amount of new inventions in technology has made in this $21^{\text {st }}$ century (Istance and Kools, 2013). For instance, the use of websites such as blogs plays a big role in every area of life. The internet united nowadays takes most parts of the world. According to Ananiadou et.al (2017) state that most language used in internet transmission is English so that it takes most of the internet users in the world. This is because English has been an international language used as the media of communication in the global internet (Lo and Lo, 2014). Meanwhile, the internet used today is fast changing and creating more media of communication among human beings. A blog is one of internet media platforms that facilitate internet users to be interacted with and share the idea of thinking. In relation to blog use, English is becoming the most language used in the blog content. A blog becomes mainstream, as news services began using them as tools for outreaching and opinion-forming (Pane, 2014). 
Nowadays, a blog takes a big part in every area of human life. A blog is a publication mechanism like journals or bulletin. Downes (2004) stated that the blog has been used not only for business, but also for educations, politics, economy, and culture. For instance, in an educational field, a blog is commonly a device to facilitate and support the communicative teaching, online classroom discussion, writing pedagogical content such as teaching method, plan, authentic assessment, learning materials, and innovation (Fageeh, 2011). Moreover, a blog is used to write online diaries as well. It is online diaries of $6^{\text {th }}$ batch SEA (Southeast Asia) teacher in St. Paul University Surigao, Philippines. The contents of online diaries are written using the English language. As a universal and worldwide language, English is used by many English foreign language learners to write their college requirements since they are coming from various countries (Coelho \& Henze, 2014). Thus, all the participants can understand the contents easily.

However, there are many sentence errors especially fragments found on online diaries of $6^{\text {th }}$ batch SEA Teacher blog writing in St. Paul University Surigao, Philippines. For instance, one of the fragments sentences from the online diaries is an incomplete verb, "She not using powerpoint because ..." (https://nar4810.blogspot.com). This sentence is omitted helping verb, namely was. It can fix the fragments by adding the helping verb, so it will be "She was not using powerpoint because ...". This sentence error case is crucial since the online diaries are read by many other EFL learners. In this case, sentence problems have been problems for EFL learners (Houraini, 2008). They tend to enact sentence errors in their English writing. Learners' mother tongue has become a factor influencing EFL learners in writing English in which they tend to combine the two systems called language transfer (Ho and Duong, 2015).

In this study, the researchers are interested in sentence error analysis especially in fragments analysis because it is advantageous for both teachers and EFL learners. It gives valid information on students' errors. Thus, it will assist the teachers in correcting the error, improving the teachers' ways in teaching, and focusing on certain areas of errors that need more reinforcement (Sawalmeh, 2013). Hussain et al (2013) also made a research on students' sentence analysis that aims to give suggestions in teaching curriculum changes in Pakistan. In that research, he found that students' writing errors were caused by several factors; physical states, memory lapses, and strong emotions. The students' weakness in English writing may commit multiple errors. Therefore, analyzing students' errors in English writing gives positive features. The language learning is already considered to the gradual exposure, hypothesizing and wide testing (Sarfraz, 2011).

\section{LITERATURE REVIEW Definition of Writing}

Four skills in English mastery have been settled as the need and obligation for those that require English as their subject of learning. Among those skills, writing is considered a complex and difficult skill since English learners have to master many elements of it, such as vocabulary, English grammar, capitalization, punctuation, and so on. According to Lee and Kim (2013) writing is a way to end up thinking something you cannot have started out thinking. When people cannot 
speak or tell something, they can write it. People can express their ideas, imagination, and feeling just by writing it.

Moreover, Langan (2008: 4) stated that writing is the transfer process from oral language to a formal or written language. On the other hand, according to Meyers (2005: 102) writing is a series of finding, exploring, arranging the concept and idea, then positioning them on a piece of paper, rethinking, rearranging, reoutlining, and revising them. It means writing is a way of organizing some massive events in a manageable layout.

Bram (1995) stated that language good writing involves knowledge and information about the convention of writing discourse in culture. Furthermore, there are some characteristics of good writing namely, 1) good content writing must have good quality in which it is suitable to reader's interest and need; 2) focus - each sentence in a paragraph or it functions as independent clause must convey one thought; 3 ) precise language - the writer must be able to choose kind of information to include or burden the readers.

\section{Error Sentences}

According to Langan (2011) error sentences have three types. Those are fragments, run on sentences, and dangling modifiers. They will be explained more as follow:

a. Fragment

Fragment is like a phrase or it may a dependent clause that can run as a sentence. A fragment expresses an incomplete thought; a fragment cannot function as a simple sentence. It is commonly called as an unfinished sentence that cannot create a complete meaning.

b. Run on sentence

Run on sentence is used to called as a too long sentence. It has two clauses or more that are improperly gathered. The run-on sentences do not tell the readers where the sentences start or end.

c. Dangling Modifier

Dangling modifier is a modifier that unlocks a sentence must be come after by the word it is intended to describe. If not, the modifier is regarded a dangling, and the sentence takes on an unplanned meaning.

\section{Fragment}

Boardman and Ngangbam (2016) state that a fragment is an incomplete idea that tries to stand alone as a sentence. Moreover, Langan (2011: 535) fragment seems to a phrase or dependent clause. It is an unfinished sentence that expresses an incomplete thought. Thus, it cannot perch alone as a simple sentence. Zheng and Park (2013) highlighted that fragment can be from a set of words which is not a sentence completely, yet it is punctuated as if it were. In conclusion, sentence fragments are lack of some elements, such as lack of subject, predicate or partial verb, and wrong punctuation; therefore, it cannot function as a sentence.

According to Wang and Guo (2014), there are several types of fragment namely 1) Missing subject fragment - it has no subject in a sentence; 2) missing verb or part of verb fragment - it is a word group punctuated as a sentence lack or has an incomplete verb; 3) beginning with infinitives or -ing words fragment; 4) fragments which are only details or example. Moreover, Langan (2011: 456) 
defined that fragment is divided into three types namely dependent word fragment, -ing words fragment, and added-detail fragment.

\section{Online Diaries}

According to Sadeg et al (2015), a diary is a documentation record with discontinuous input and entries accomplished by date reporting about a certain period activity. There are two types of diaries, namely offline and online diaries. The offline one usually wrote originally in a handwritten format in a personal account book. In contrast, an online diary is a record in which the writer wrote it in a computer screen (digital written) about what has happened for a day or other periods (Kitchakarn, 2014), then she uploaded it to her blog, social media, and so on.

\section{Blog}

A blog is similar to a website. Galien and Bowcher (2010) mention that a blog is regarded an instrument for linking, communicating, and interacting among human beings in dissimilar languages. A blog is a platform in which the writers can write or share their views and information in the reverse in chronological order, with the latest posts appearing first (Pane, 2014). Besides, a blog is a diary or journal that is maintained by one person, or it can be called a blogger. Krapi (2017) stated that a blog usually uses to express his or her own opinions, personal beliefs, descriptions of events, or simply personal views regarding a certain topic. In an educational field, a blog has four basic functions, namely classroom management, teaching and learning collaboration, discussion, and portfolios.

\section{RESEARCH METHOD}

This study applied a quantitative research method is trying to report and describe the sentence fragments found in ten formal online diaries of $6^{\text {th }}$ batch SEA Teacher Blog Writing in St. Paul University Surigao, Philippines as well as the problems faced by the SEA Teacher students. In this study, the researchers took all the newest online diaries as the objects of this study. In a year, there are ten students who join the SEA Teacher program that means there will be ten online diaries available in the blog. Considering this fact, the researchers took all the newest diaries as the objects. The unit analysis is a sentence on online diaries. The researchers analyzed ten formal online diaries and also distributed a questionnaire to the writers (participants) of the online diaries. The questionnaire is aimed to gain information about problems made by SEA teacher students. For analyzing the data, the researchers use descriptive statistical analysis by using the percentage.

\section{FINDING AND DISCUSSION \\ Finding}

1. Fragments found on online diaries of $6^{\text {th }}$ batch SEA Teacher blog writing in St. Paul University Surigao, Philippines

This data source of this study was collected through formal online diaries of $6^{\text {th }}$ batch SEA Teacher Blog Writing in St. Paul University Surigao, 
Philippines, and the data from questionnaires. The researchers analyzed ten formal online diaries. From ten formal online diaries, the researchers found fragments on seven formal online diaries, and she did not found fragments on the rest. Those ten fragments mostly caused by missing subjects and verbs. Related to the data showed before, the researchers presented the graphic 1, as follows:

\section{Graphic 1}

\section{Fragments found in Online Diaries of $6^{\text {th }}$ SEA Teacher Blog Writing}

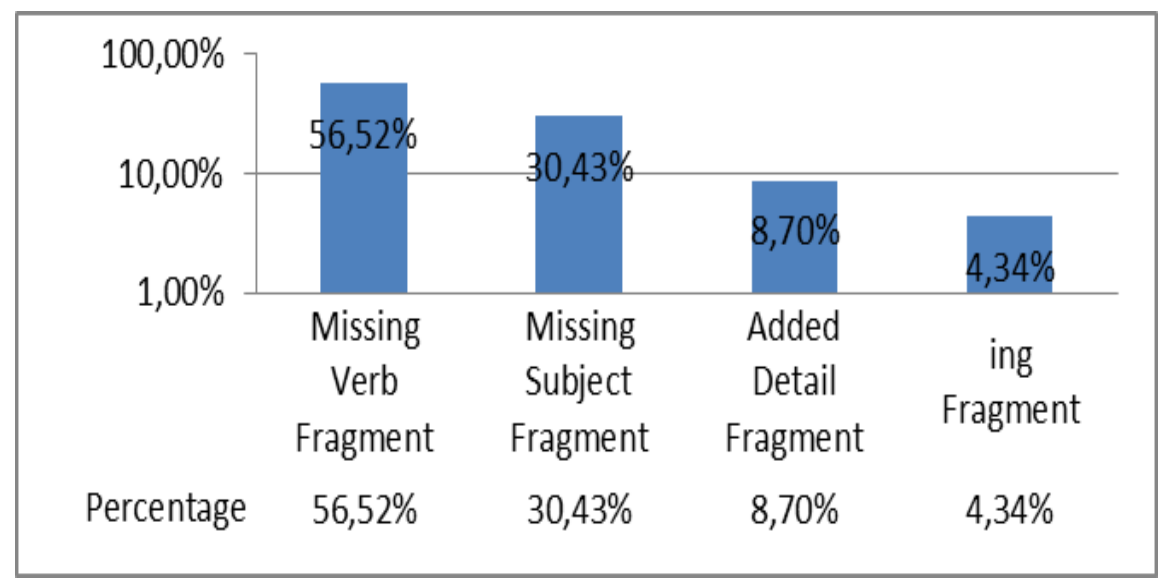

From the graphic 1 above, it can be seen that missing verb fragment has the highest percentage, namely $56.52 \%$. Then, missing subject fragment $(30.43 \%)$ followed by adding detail fragment $(8.70 \%)$, and -ing fragment (4.34\%). For more explanation, the writer gave some examples from the codes mentioned before. The examples were as follows:

a. Missing verb fragment

1) ( $S$-V-02) When the time almost over, I repeat again I deliver to them. This sentence clearly had no verb in the sentence. Therefore, the writer added a verb "is /was" in the fragment. The use of "is/was" verb depended on the exact time. The exact time affected to what type of tenses should be used. The sentence would be "When the time was almost over, I repeated again I deliver to them." A good sentence might have at least a subject and verb to express one complete thought.

2) (S-V-04) ... I usually giving them the questions about the lesson, for example ...

For this sentence, it did not have any verb that expresses one complete thought. For correcting it, the writer inserted "am/was" verb to the sentence. The use of "am/was" verb depended on the exact time. The exact time affected by what type of tenses should be used. Since this was recount text about an online formal diary, thus, the sentence became "...I usually was giving them the questions about the lesson, for example ....

b. Missing subject fragment 
1) (S-VI-02)Then, give explanation about the material or making brainstorming to catch students' attention.

For this sentence, it did not have a subject that explained who had done the action. Thus, the writer added a subject "I" in the sentence. "I" subject was the one who had done certain actions. Thus, the sentence would be "Then, I give explanation about the material or making brainstorming to catch students'attention."

2) (S-X-01) After week of observation, now is the time for me to practice teaching.

This sentence did not have a subject which explained pronoun for having time to practice teaching. Therefore, the writer fixed the fragment by adding a subject "it" to the sentence. "It" subject was the pronoun for having time to practice teaching. The sentence would be "After a week of observation, now it is the time for me to practice teaching."

c. Added detail fragment

1) (S-I-03) also their personality.

This phrase is a fragment because it does not have any clauses. For this fragment, it included as an added detail fragment. For fixing it, the writer combined the phrase with the previous sentence. The previous sentence was "For me, to remember their name was very difficult, yet to familiarize their face were very easy to me. Also their personality, so the sentence would be "For me, to remember their name was very difficult, yet to familiarize their face also their personality was very easy to me.

d. -ing fragment

(S-II-01) following the teaching plan made by me and consultation with my cooperating teacher. For this fragment, it could include to -ing fragment. For fixing it, the writer added a subject "it" and a verb "is/was", so the sentence would be "After that, preparing students in their learning process by showing outcomes that would be the goal of learning at the time. It was following the teaching plan made by me and consultation with my cooperating teacher." Most fragments caused by many problems. For instance, missing verb fragments which have the highest percentage in the online diary caused by the participants were lack of grammar knowledge.

\section{Problems faced by $6^{\text {th }}$ batch SEA Teacher in writing online diaries.}

Another data source of this study was a questionnaire which included nine questions. It consisted of closed and opened ended questions covering the research question as well as subject related. The questions in the questionnaire set to obtain information about participants' problems faced when writing formal online diaries.

Table 1

Participants' Response Related to Problems in writing online diaries

\begin{tabular}{|l|l|l|}
\hline No & Question Topic & Percentage \\
\hline
\end{tabular}




\begin{tabular}{|c|c|c|c|}
\hline & & & \\
\hline & & Yes & No \\
\hline 1 & $\begin{array}{l}\text { Do you enjoy writing formal online diaries for } \\
\text { report the requirement of the } 6^{\text {th }} \text { batch SEA } \\
\text { Teacher Program? }\end{array}$ & 100 & 0 \\
\hline 2 & $\begin{array}{l}\text { Do you feel good and confident in your ability to } \\
\text { convey your ideas on writing online diaries for } \\
\text { report the requirement of the } 6^{\text {th }} \text { batch SEA } \\
\text { Teacher Program? }\end{array}$ & 90 & 10 \\
\hline 3 & $\begin{array}{l}\text { Do you trust yourself as a person who can find } \\
\text { correct words and ideas and perceptions on } \\
\text { writing online diaries for report the requirement } \\
\text { of the } 6^{\text {th }} \text { batch SEA Teacher Program? }\end{array}$ & 80 & 20 \\
\hline 4 & $\begin{array}{l}\text { Can you easily write on any relevant topic of } \\
\text { formal online diaries for report requirement of } \\
\text { the } 6^{\text {th }} \text { batch SEA Teacher Program? }\end{array}$ & 80 & 20 \\
\hline 5 & $\begin{array}{l}\text { On writing formal online diaries, can you } \\
\text { generate lots of words fairly, quickly, and freely } \\
\text { - not be stuck? }\end{array}$ & 80 & 20 \\
\hline & Total & 95.55 & 15.55 \\
\hline
\end{tabular}

From table 1 above, it was known that all participants of the SEA teacher enjoyed writing formal online diaries for report requirements of the $6^{\text {th }}$ batch SEA Teacher Program $(100 \%)$. Most of them also felt confident when writing formal online diaries (90\%), only one participant who did not feel confident $(10 \%)$. Moreover, the participants trusted themselves as a person who could get correct words and ideas and perceptions on writing online diaries (80\%), however, some of them did not trust themselves (20\%). Most of the participants easily wrote on any relevant topic of formal online diaries as their report in the SEA Teacher program (80\%) as well, in contrast, two participants got a hard time for writing it (20\%). Many of them could generate lots of words fairly, quickly, and freely - not be stuck ( $80 \%)$, but some of them could not generate it (20\%).

In addition, according to questionnaire item number six and seven, the participants also faced many problems when writing formal online diaries i.e. lack of grammar knowledge, time for writing formal online diaries, reference for writing it, and language (translation from a source language (Bahasa Indonesia) to the target language (English)). Here was the calculation of problems were faced by the $6^{\text {th }}$ batch SEA Teacher in St. Paul University Surigao, Philippines in writing online diaries. The table 2 below gave a statistical summary of the problem faced by participants when writing formal online diaries. The order was stated from the hardest to the easiest.

Table 2

The Frequency of Problems in Writing Online Diaries

\begin{tabular}{|l|lc|c|c|}
\hline No & $\begin{array}{l}\text { Problems in writing } \\
\text { online diaries }\end{array}$ & Frequency & Percentage \\
\hline 1 & Lack of grammar & 8 & $47.05 \%$ \\
\hline
\end{tabular}




\begin{tabular}{|l|l|c|c|}
\hline & knowledge & & \\
\hline 2 & Time limitation for writing & 4 & $23.52 \%$ \\
\hline 3 & Lack of writing reference & 3 & $17.64 \%$ \\
\hline 4 & Different language used & 2 & $11.76 \%$ \\
\hline \multicolumn{2}{r|}{ Total } & 17 & $99.97 \%$ \\
\hline
\end{tabular}

Grammar knowledge was the highest problem faced by the participants when writing formal online diaries $(47.05 \%)$. It was followed by time for writing as the second most problem faced by the participant $(23.52 \%)$. The participants also still lacked reference for writing $(17.64 \%)$, then followed by the language used $(11.76 \%)$.

\section{Discussion}

According to Hourani (2008) explained that writing for EFL students is a complex process of transferring the idea and thinking. For EFL students, composing a good writing is a big matter. It is commonly found some errors in writing. Moreover, Wu and Garza (2014) stated that error analysis is applied for analyzing the speech and written form of foreign language learners. In this study, the writer focused on discussing fragments. From the analysis above, it found many fragments on an online diary of $6^{\text {th }}$ batch SEA teacher blog writing in St. Paul University Surigao, Philippines, namely missing subject, verb, detailed, and v-ing fragments. In the finding, missing subjects and a verb become the most dominant one. It happened for some reason such as lack of grammar knowledge, and failed transfer language from the source language (Bahasa Indonesia) to target language (English language). Furthermore, Sermsook (2017) et al stated that types of fragments found in sentences committed by EFL Thai students were no subject and verb. Failed transfer of mother language, incomplete knowledge of target language, different rules of words order and sentence became the main problems which led to sentence fragments (Hinnon, 2014).

Besides missing subject and verb fragment, only detailed and v-ing fragment also stated in the finding. In contrast, this finding is different from Ananda et al's study (2014), they found that there were several fragmented sentence errors such as the subject absence/missing, a verb, both a subject and a verb, a verb in a dependent clause and an independent clause. To sum up, all the fragments were serious problems in students' writing.

Moreover, the researchers found that there were some problems faced by them once writing it, namely lack of grammar knowledge, time for writing, reference for writing, and language used. In the questionnaire result, in item number six found that eight participants had problems in grammar knowledge. It was a problem that made them missing some fragments, such as missing subject, verb, detailed, and v-ing fragments. This finding is close with a previous study undertaken by Zheng and Park's (2013), they found that lack of grammar led to sentence error. From their analysis of English essays that were composed by EFL students in China and Korea, they had a problem in using punctuation mark, ordering words, and articles which cause sentence fragment. Moreover, the writers 
of the online diary were unaware of combining two kinds of tenses in the same sentence or paragraph. Zafar (2016) stated clearly that the most problematic ones of creating writing exercise were tenses uses. The lack of using accurate tense made sentence fragment led to misunderstanding. Grammar and writing are in special "cooperation" in which writing skill needs formal language patterns, standard grammar, and mechanics of writing (Taiseer, 2008).

The most second problem was time for writing. Time for writing became a crucial problem as well for the participants when writing a formal online diary. The participants felt a lack of time for writing a formal online diary. Besides, they had to write a formal online diary, they had to write all their activities since their first day there until the last day as well. The participants were given time for writing an online diary not more than 30 days. It was lucky for them who remembered all the activities for 30 days there. In contrast, if they forgot it, they had to call on their memories again. Of course, it spent much more time. In addition, the duty was not only to write the online diary but also the participants should make a blog for posting the document. If the participants have mastered the way how to make a blog, use it, edit it, and upload it, it was good. However, many of them still did not know about that, so they have to learn it first. The time had given did not run out for writing an online diary, but it runs out for learning how to make and use a blog as well.

The next problem was a reference for writing. The institute which held the SEA Teacher program (SEAMEO) did not give a certain reference for writing it. Also, SEAMEO had given online orientation regarded to writing the online diary and guideline for writing it. For online orientation became a new problem for the participants. Every participant has a different geographical area in which a certain geographical area had a hard time having a good internet connection. If the participant missed the online orientation, they would miss the reference for writing. Moreover, although they had given the guideline for writing it, the participants were still confused as there were many points of requirement which were the same as the previous points. Besides, although there were references from the previous batch, it did not help so much as between one participant and others were different. What participants expected was different from the institution related to the online diary. The misunderstanding between each other would cause the participants' certificate delayed.

The last problem was the different languages used by respondents. The language used and grammar knowledge was related to each other. As linguistically known, the nature of English grammar and structure is concerned with the rules and systems on the level of sound, words or lexicons, clauses and sentences, and meaning (Myhil \& Watson, 2014). Nature is tied to a variety of features either universal or unique. If English grammar and the grammar of bahasa Indonesia are compared, for example, some differences, As well as similarities, are easily found. One of the important differences is that English is a tense language, while bahasa Indonesia (and the majority of Malayan languages) are tenseless language (Jufrizal, 2013). Another difference can be seen in aspect, modality, and phrase structure. In English, aspect and modality are expressed in the predicate; while in bahasa Indonesia they are simply expressed through lexical items. Such grammatical differences may be parts of important reasons to say that learning EFL grammar is necessary for Indonesian learners. Actually, the 
language was not a big problem since as Indonesian - our second language is English. It became a problem once translating from Bahasa Indonesia to English. English foreign learners generally translated their mother tongue language into English word by word. Sometimes, the participants did not know what the correct dictions should use. This result is congruent with Watcharapunyawong and Usaha's study (2013). They studied the sentencing error of Thai students. It happened since the interference of their mother tongue, namely Phasa Thai. Their mother tounge had a strong influence on students' language, especially in writing. Different lexical, syntactic, and discourse-level between Phasa Thai and English become the problematic one. From the explanation above, the researchers noticed that the fragment occurred because of participants' grammar knowledge lack. It caused a lack of readability and coherence. If the sentence was lack of readability and coherence, it would cause misinterpreting for the readers to catch what the writer meant. Moreover, the participants got careless because they were confused and calm less on how to arrange the words into good grammatical orders.

\section{CONCLUSION AND SUGGESTION}

From the study above, several conclusions can be formulated, as following: 1) There were several fragment types found on online diaries of $6^{\text {th }}$ batch sea teacher blog writing in St.Paul University Surigao, Philippines namely missing verb fragment, missing subject fragment, added detail, fragment, and -ing fragment; The missing verb fragment became the dominant mistake done by the participants $(56,52 \%)$. Then, missing subject fragment $(30.43 \%)$ followed by added detail fragment $(8.70 \%)$, and -ing fragment $(4.34 \%) ; 2$ ) fragments appeared in the formal online diaries because of many problems, such as the lack of grammar knowledge, time for writing, reference for writing, and language. Grammar knowledge was the highest problem faced by the participants when writing formal online diaries $(47.05 \%)$. It was followed by time for writing as the second most problem faced by the participant $(23.52 \%)$. The participants were also still lack of reference for writing $(17.64 \%)$, then followed by the language used $(11.76 \%)$.

Furthermore, the researchers would like to give some suggestions to the participants, the institution which held the SEA teacher program, and the next researcher. For the participants, the participants should learn more about grammar knowledge for avoiding some fragments in the future. They also should increase their writing skill. For the institutions (SEAMEO), it should kindly be clear with the guideline, and parameter with the report (formal online diaries), because the participants found out that there were some points of requirement which were the same with the previous points. The guideline can be the reference for writing formal online diaries, so it should be the clear one. For the next researcher, it is expected that this study can be a reference for the next researchers in conducting further research related to sentence error.

\section{REFERENCES}

Ananda, R., Gani, S. A., \& Sahardin, R. (2014). A Study of Error Analysis from Students' Sentences in Writing. Studies in English Language and Education, 1(2), 81-95. Retrieved from http://www.jurnal.unsyiah.ac.id/SiELE/article/view/1828/1724 
Ananiadou, S., McNaught, J., Thompson, P., Rehm, G., \& Uszkoreit, H. (2012). The English Language in the digital age. Springer.

Anfara Jr, V. A., \& Mertz, N. T. (Eds.). (2014). Theoretical frameworks in qualitative research. Sage publications.

Boardman, C. A., \& Frydenberg, J. (2008). Writing to communicate 2: Paragraphs and essays. Pearson/Longman.

Brown, H. D. 2000. Teaching by Principles An Interactive Approach to Language Pedagogy Second Edition. California: Longman.

Coelho, F. O., \& Henze, R. (2014). English for what? Rural Nicaraguan teachers' local responses to national educational policy. Language Policy, 13(2), 145163. Retrieved from https://link.springer.com/article/10.1007/s10993-0139309-4

Downes, S. (2004). Educational blogging. Educause review, 39(5), 14-21.

Fageeh, A. I. (2011). EFL learners' use of blogging for developing writing skills and enhancing attitudes towards English learning: An exploratory study. Journal of Language and Literature, 2(1), 31-48

Galien, Patricia., and Bowcher, Wendy L. 2010. Using Blogs in ESLEFL Teaching and Teacher-Training. Asian EFL Journal, 42: 4-23. Retrieved from https://www.asian-efl-journal.com/monthly-editions-new/usingblogs-in-eslefl-teaching-and-teacher-training/

Hinnon, A. (2014). Common errors in English writing and suggested solutions of Thai university students. มนุษยศาสตร์สังคมศาสตร์. Retrieved from https://so01.tci-thaijo.org/index.php/HUSO/article/view/32281/27570

Hingne, P. G. (2013). Impressive tool to communicate in modern world is the language English. International Journal of Social Science and Humanity, 3(3), $319 . \quad$ Retrieved from https://pdfs.semanticscholar.org/3e06/31142300eeebc242359f30056361a7c5 a979.pdf

Ho, P. V. P., \& Duong, P. N. T. (2015). Common Errors in Writing Journals of the English-Major Students at HCMC Open University. Journal of Science Ho Chi Minh City Open University-No, 2(14).

Hourani, T. M. Y. (2008). An analysis of the common grammatical errors in the English writing made by 3rd secondary male students in the Eastern Coast of the UAE.

Istance, D., \& Kools, M. (2013). OECD work on technology and education: Innovative learning environments as an integrating framework. European Journal of Education, 48(1), 43-57. https://doi.org/10.1111/ejed.12017 
Jufrizal, J., \& Refnita, L. (2013). The Cultural-Academic Gaps faced by the EFL Learners in Understanding and Using English Tenses. Leksika: Jurnal Bahasa, Sastra dan Pengajarannya, 7(1). Retrieved from http://www.jurnalnasional.ump.ac.id/index.php/LEKSIKA/article/view/111

Kitchakarn, O. (2014). Developing Writing Abilities of EFL Students through Blogging. Turkish Online Journal of Distance Education, 15(4), 34-47. Retrieved from https://eric.ed.gov/?id=EJ1092806

Ngangbam, H. (2016). An analysis of syntactic errors committed by students of English language class in the written composition of Mutah University: A case study. European Journal of English Language, Linguistics and Literature, 3(1), 1-13. Retrieved from https://scholar.google.co.id/scholar?hl=id\&as_sdt=0\%2C5\&as_ylo=2013\&a $\underline{\text { s_yhi }=2016 \& q=\text { sentence }+ \text { fragments }+ \text { analysis \&btnG }}$

Taiseer, M. (2008). An analysis of the common grammatical errors in the English writing made by 3rd secondary male students in the Eastern Coast of the UAE. Unpublished Master's Thesis. Institute of Education British University in Dubai-UAE.

Krapi, Fjoralba. 2017. Awareness and Effectiveness of Corporate Blogging in Companies in Kosovo. Thesis. Rochester Institute of Technology.

Langan, John. 2008. College Writing Skill with Reading Seventh Edition. New York: McGraw Hill Companies.

Langan, John. 2011. College Writing Skill with Reading Eighth Edition. New York: McGraw Hill Companies.

Lee, K. J., \& Kim, J. E. (2013). A mobile-based learning tool to improve writing skills of EFL learners. Procedia-Social and Behavioral Sciences, 106, 112119. Retrieved from https://core.ac.uk/download/pdf/82777041.pdf

Lo, Y. Y., \& Lo, E. S. C. (2014). A meta-analysis of the effectiveness of Englishmedium education in Hong Kong. Review of Educational Research, 84(1), 47-73. https://doi.org/10.3102\%2F0034654313499615

Meyers, Alan. 2005. Gateway to Academic Writing: Effective Sentence, Paragraphs, and Essays. London: Longman Group.

Myhill, D., \& Watson, A. (2014). The role of grammar in the writing curriculum: A review of the literature. Child Language Teaching and Therapy, 30(1), 41-62. Retrieved from https://journals.sagepub.com/doi/abs/10.1177/0265659013514070

Pane, Pamela. 2014. How Does the Use of Blogs Impact Student Motivation for Literature Discussions? Journal of Inquiry \& Action in Education, 5(3), 7090.https://digitalcommons.buffalostate.edu/jiae/vol5/iss3/5/ 
Sadeg, T. M., Akbar, R. S., Taqi, H. A., \& Shuqair, K. M. (2015). EFL writing students' perception of the effect of diary writing. European American Journals, 3(2), 54-63.

Sarfraz, S. (2011). Error analysis of the written English essays of Pakistani undergraduate students: A case study. Asian Transactions on Basic \& Applied Sciences, 1(3), 29-51.

Sawalmeh, M. H. M. (2013). Error analysis of written English essays: The case of students of the preparatory year program in Saudi Arabia. English for Specific Purposes World, 14(40), 1-17.

Sermsook, K., Liamnimit, J., \& Pochakorn, R. (2017). An Analysis of Errors in Written English Sentences: A Case Study of Thai EFL Students. English Language Teaching, 10(3), 101-110. Retrieved from https://eric.ed.gov/?id=EJ1130033

Wang, Y., \& Guo, M. (2014). A short analysis of discourse coherence. Journal of Language Teaching and Research, 5(2), 460. Retrieved from https://pdfs.semanticscholar.org/c02b/11f87454de583946d985c023b7b61c1 df3c3.pdf

Watcharapunyawong, S., \& Usaha, S. (2013). Thai EFL Students' Writing Errors in Different Text Types: The Interference of the First Language. English Language Teaching, 6(1), 67-78. Retrieved from https://eric.ed.gov/?id=EJ1076889

Wu, H. P., \& Garza, E. V. (2014). Types and Attributes of English Writing Errors in the EFL Context-A Study of Error Analysis. Journal of Language Teaching \& Research, 5(6). Retrieved from https://scholar.google.co.id/scholar?hl=id\&as_sdt=0\%2C5\&q=Types+and+ Attributes+of+English+Writing+Errors+in+the+EFL+Context-

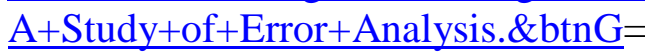

Zafar, Ameena. (2016). Error analysis: a tool to improve English skills of undergraduate students. Procedia-Social and Behavioral Sciences, 217: 697705. Retrieved from https://scholar.google.com/scholar?hl=en\&as_sdt=0\%2C $5 \& \mathrm{q}=+$ Error+analy sis\%3A+A+tool+to+improve+English+skills+of+undergraduate+students \& $\underline{\mathrm{btnG}}=$

Zheng, C., \& Park, T. J. (2013). An analysis of errors in English writing made by Chinese and Korean university students. Theory and practice in language studies, 3(8), $1342 . \quad$ Retrieved from https://scholar.google.co.id/scholar?hl=id\&as_sdt=0\%2C5\&as_ylo=2013\&a s_yhi $=2016 \& q=$ sentence + fragments + analysis $\& b t n G=$

\section{Authors' Brief CV}

$1^{\text {st }}$ Author.Beny Arum Setianingsih is an English lecturer assistant in the Language Centre in Universitas PGRI Semarang. She also teaches English in Eye Level Indonesia Course in Semarang. Her interest is conducting research relating to writing skills and grammar competencies. 
$2^{\text {nd }}$ Author. Entika Fani Prastikawati is currently an English lecturer at the English Department of Universitas PGRI Semarang. She has published articles in IJET, CELT Journal, Eternal Journal, and presented papers in some international conferences like in ELTLT, COTEFL, TEFLIN, ICESRE, LSC, and TEYLN Conferences.

$3^{\text {rd }}$ Author. Wiyaka is a senior lecturer at the English Department, Universitas PGRI Semarang, Indonesia. Besides teaching, he has worked with some research projects funded by the ministry of higher education and other sponsors. Among his interests in teaching and research are language assessment, reading, and writing. 